\title{
Perancangan Notifikasi Pesan Disposisi Pada Sistem Pengelolaan Surat Dinas Menggunakan Layanan API Media Social (Studi Kasus: Dinas Pertanian Kota Salatiga)
}

\author{
Billy Gerardhy Lainsamputty ${ }^{1}$, Suprihadi ${ }^{2}$ \\ ${ }^{1,2}$ Fakultas Teknologi Informasi Universitas Kristen Satya Wacana \\ Jl. Dr. O. Notohamidjojo 1-10, Salatiga 50711, Indonesia \\ Email :1672013094@student.uksw.edu, ${ }^{2}$ suprihadi@staff.uksw.edu
}

\begin{abstract}
Based on the Department of Agriculture which still does not have the tools or media to manage the letter of service, both the incoming and outgoing mail which impact on the weak supervision follow-up of the service letter due to ignorance that the letter should be processed. This study was made as a visual and text notification of incoming and outgoing mail data with more detailed archive storage. This website application is supported by using social media telegram API service that is used as notification in the form of notification to the employee so that the Service Letter can be followed up immediately.
\end{abstract}

Keywords: Notifications, APIs, Social Media, Mail Management, Website

\begin{abstract}
Abstrak
Didasarkan pada Dinas Pertanian yang masih belum memiliki alat atau media untuk mengelola surat dinas, baik surat masuk maupun surat keluar yang berdampak pada lemahnya pengawasan tindak lanjut dari surat dinas tersebut yang dikarenakan ketidaktahuan bahwa adanya surat yang harus segera diproses. Penelitian ini dibuat sebagai pemberitahuan visual dan teks tentang data surat yang masuk dan keluar juga dengan penyimpanan arsip yang lebih terperinci. Aplikasi website ini didukung dengan menggunakan layanan API Media Social Telegram yang digunakan sebagai pemberitahuan dalam bentuk notifikasi kepada pegawai agar Surat Dinas agar dapat segera ditindak lanjuti.
\end{abstract}

Kata kunci: Notifikasi, API, Media Social, Pengelolaan Surat, Website

\section{Pendahuluan}

Perkembangan teknologi informasi khususnya teknologi website dan pemanfaatan Application Programming Interface (API) sebagai sarana notifikasi semakin pesat dan bervariasi. Saat ini, website memiliki fungsi tidak lagi sebagai sumber informasi dan bersifat pasif, tetapi telah dikembangkan dapat bersifat dinamis. Oleh karena itu, peran website menjadi media komunikasi dua arah dan memiliki proses timbal balik dengan pengguna. Perkembangan teknologi website tersebut sejalan dengan Inpres No. 3 tahun 2003 tentang kebijakan dan strategi 
nasional pengembangan elektronik government. Inpres No. 3 tahun 2003 tersebut juga berisi tentang pertimbangan pemanfaatan teknologi informasi dalam alur layanan pemerintahan dalam upaya peningkatan efesiensi, efekstivitas, transparansi serta penyelenggaraan pemerintahan yang akuntabel. Dengan teknologi website saat ini, diharapkan juga diperoleh aliran data dan informasi yang lebih optimum antara lembaga pemerintahan dengan masyarakat, dan sebaliknya, sehingga peran website bagi publik dapat dipergunakan sebagai penyambung aspirasi. Dengan demikian, efesiensi dan efektivitas dalam penyelenggaraan pemerintahan dapat ditingkatkan melalui perkembangan teknologi website yang dinamis.

Berdasarkan wawancara dengan Kepala Dinas, dan juga kepada para pegawai di lingkungan Dinas Pertanian Kota Salatiga, diketahui bahwa sebagian besar para pegawai sulit dalam mengakses dan membutuhkan waktu cukup lama dalam mamperoses surat masuk maupun surat keluar, yang disebabkan karena mekanisme pemberitahuan informasi terkait surat yang harus diproses belum dilakukan secara realtime. Kepala Dinas pun tidak dapat memonitoring aktivitas laporan kemajuan tindak lanjut surat hasil proses yang ditujukan bagi para pegawai karena tidak adanya record yang menyimpan terkait surat tersebut.

Penyampaian pesan atau informasi pada era globalisasi dapat melalui berbagai media antara lain media sosial, media electronik dan media cetak. Pemilihan media dalam menyampaikan pesan harus didasarkan pada isi pesan yang akan dikirim maupun diterima. Sistem yang diusulkan dalam penelitian ini yaitu dengan memanfaatkan teknologi notifikasi menggunakan notifikasi media sosial, karena dianggap efisien dalam penggunaan waktu dan media sosial cukup dikenal oleh para pegawai dinas pertanian Kota Salatiga. Selain itu, sarana mengakses juga cukup menggunakan smartphone sederhana sehingga dapat dibawa kemana-mana, diharapkan pesan dapat diterima secara tepat dan cepat.

Berdasarkan latar belakang tersebut, maka penelitian ini bertujuan merancang sistem pada sebuah aplikasi website yang menggunakan API yang digunakan sebagai media memperoses surat dan media pengingat tentang adanya surat yang harus segera diproses. Pembangunan sistem berbasis web karena website lebih mudah digunakan oleh semua kalangan masyarakat, sedangkan pemanfaatan teknologi API digunakan sebagai media pemberitahuan atau notifikasi kepada para pegawai Dinas Pertanian Kota Salatiga secara uptodate agar para pegawai dapat segera melakukan proses tindak lanjut pada surat yang diterima. Notifikasi akan diterima para pegawai melalui sosial media yang telah ditentukan pada penelitian ini.

Adapun batasan masalah pada penelitian ini adalah media notifikasi ini dibangun menggunakan platform website, API yang digunakan adalah API yang disediakan oleh aplikasi media sosial yang dipilih, pesan yang dikirim adalah info 
AITI: Jurnal Teknologi Informasi

Volume 16 No. 2 Agustus 2019, 165-186

sederhana dalam bentuk teks, tidak membahas keamanan data, dan tidak membahas kecepatan notofikasi yang disebabkan faktor bandwith internet.

\section{Tinjuan Pustaka}

Penelitian yang dilakukan Maulana (2015) di Kabupaten Garut menggunakan framework dan bahasa pemrograman PHP telah menghasilkan suatu aplikasi yang mampu mengelola surat masuk dan surat keluar secara lebih efektif, baik dalam segi waktu, tenaga dan biaya. Hal tersebut disebabkan karena aplikasi mampu memberi pengaruh pada prosedur kerja, antara lain proses penyimpanan dan pencarian dokumen surat. Pengembangan sistem informasi ini yang diperlukan adalah menyediakan layanan pembuatan laporan dokumen surat kepada pegawai berdasarkan periode yang diinginkan [1].

Pada penelitian Fitriana (2015), telah dikembangkan sistem pengolahan yang dapat membantu pegawai dalam mengelola proses input surat masuk dan surat keluar. Meningkatkan sistem pengangendaan surat dari sistem manual menjadi sistem terkomputerisasi yang membuat proses pengarsipan surat terintegrasi antara bagian dan adanya backup surat apabila surat asli hilang atau rusak. Dengan pengolahan database berbasis elektronik menjadikan data mitra kerja lebih cepat diakses [2].

Pada penelitian Hasan (2016), didapatkan pada penelitian ini penggunaan Application Programming Interface (API) yang mampu memberikan informasi kepada mahasiswa dalam melihat jadwal bimbingan agar para mahasiswa dapat menerima informasi secara realtime dan up to date. Aplikasi tersebut dapat memberi informasi kepada mahasiswa mengenai jadwal bimbingan yang diberikan dosen, agar para mahasiswa dapat melakukan bimbingan tepat waktu sesuai jadwal dengan melakukan request. Aplikasi telah berguna khususnya bagi mahasiswa dalam melakukan proses bimbingan agar sesuai dengan ketentuan waktu yang telah diinformasikan oleh dosen pembimbing [3].

Pada penelitian ini telah dilakukan Perancangan Sistem Notifikasi Pesan Disposisi Pada Pengelolaan Surat Menggunakan Layanan API Media Social (Studi Kasus: Dinas Pertanian Kota Salatiga). Sistem dirancang berbasis website application yang mampu memberikan notifikasi pada sosial media dengan memanfaatkan Application Programming Interface (API) yang disediakan media sosial tersebut, sehingga dapat memberikan informasi pesan adanya surat secara realtime kepada para pegawai, dan membantu memudahkan pengelolaan dokumen surat di lingkungan Dinas Pertanian Kota Salatiga.

Application Programming Interface (API) adalah sebuah teknologi untuk memfasilitasi pertukaran informasi atau data antar aplikasi perangkat lunak. API adalah antarmuka virtual antara dua fungsi aplikasi yang saling bekerja sama. API dapat berisi teknik programmer dalam memanfaatkan suatu fitur tertentu dari 
sebuah komputer. Dengan demikian, API dapat tersedia dalam sistem windowing, sistem file, sistem basis data dan sistem jaringan [4].

Sebuah situs Website dapat didefinisikan sebagai kumpulan halamanhalaman elektronik atau web page yang berisi informasi atau data. Sebuah website pada umumnya memiliki alamat penunjuk yang unik, yaitu domain, biasanya memiliki konten terdiri dari tipe format teks, gambar, tabel, grafik, kutipan, video, audio, dan format visual lainnya. Website diakses publik melalui internet protocol (IP) dalam sebuah jaringan internet, atau diakses secara offline melalui jaringan LAN. Website dilihat dari sisi pemilik, dapat dikelompokkan antara lain website pribadi, komersial, pemerintahan, dan lainnya bahkan untuk kepentingan laba maupun nirlaba yang dipublikasikan secara umum. Selain itu, website dilihat dari sisi fungsi, dapat digolongkan tujuan khusus antara lain untuk hiburan, pendidikan, dan sosial [5].

Telegram adalah sebuah aplikasi servis pengiriman message instan yang tidak dibatasi platform berbasis cloud yang dapat diakses secara gratis dan non profit. Klien Telegram dapat dari berbagai platform perangkat seluler dan sistem operasi komputer. Pesan pada Telegram dapat berisi image, video, audio, stiker, dan semua tipe berkas, dan disediakan layanan pengiriman pesan terenkripsi secara opsional. Layanan Telegram ini berupa API yang dapat dipergunakan pengembang independen. Pada 2016, aplikasi Telegram telah diakses 100 juta pengguna aktif di tiap bula, serta telah melakukan transaski pengiriman 15 miliar pesan per hari [6].

\section{Metode Penelitian}

Penelitian yang telah dilakukan melalui tahapan sebagai berikut: 1) Identifikasi Masalah. 2) Pengembangan Sistem. 3) Pengujian Sistem dan Analisis Hasil Pengujian. 4) Penulisan Laporan.

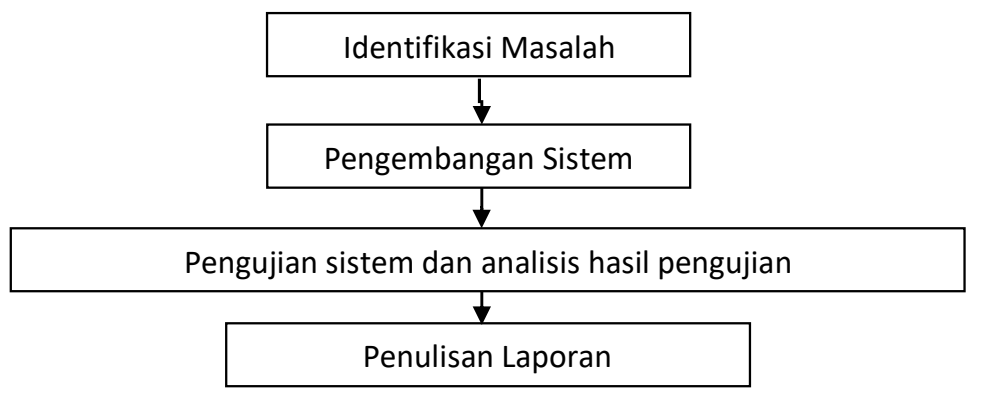

Gambar 1 Tahap Penelitian

Gambar 1 menjelaskan bahwa tahap awal dilakukan identifikasi masalah, yaitu melakukan pengamatan tentang proses bisnis yang dijalankan, dan menganalisis masalah-masalah yang terjadi pada Dinas Pertanian Kota Salatiga terkait pengelolaan surat masuk dan keluar, dan proses disposisi surat tugas, serta proses progress report pegawai terhadap surat tugas yang diberikan. Pada tahap ini 
AITI: Jurnal Teknologi Informasi

Volume 16 No. 2 Agustus 2019, 165-186

juga dilakukan wawancara kepada Kepala Dinas dan juga beberapa pegawai tentang faktor apa saja yang menjadi penghambat selama proses bisnis terjadi.

Tahap pengembangan sistem, yaitu kegiatan pembangunan sistem dengan diawali proses perancangan sistem menggunakan metode Unified Modeling Language (UML). Tahap ini juga dilakukan perancangan arsitektur sistem, yaitu untuk mengetahui kebutuhan platform aplikasi yang digunakan, khususnya posisi Application Programming Interface Telegram yang berfungsi memberikan layanan notifikasi secara realtime. Metode pengembangan sistem yang digunakan pada penelitian ini adalah metode prototype, karena aplikasi yang dihasilkan supaya dapat lebih sesuai dan tepat seperti yang diharapkan para aktor pengguna di Dinas Pertanian Kota Salatiga.

Tahap pengujian sistem dan analisis hasil pengujian dilakukan pada sistem aplikasi pengolahan surat pada Dinas Pertanian Kota Salatiga tersebut melalui media kuisioner. Dilanjutkan tahap akhir yaitu penulisan laporan yaitu mendokumentasikan hasil rancangan, pengembangan sistem, dan hasil pengujian kedalam bentuk laporan tugas akhir dan artikel ilmiah guna publikasi ke jurnal ilmiah yang bereputasi.

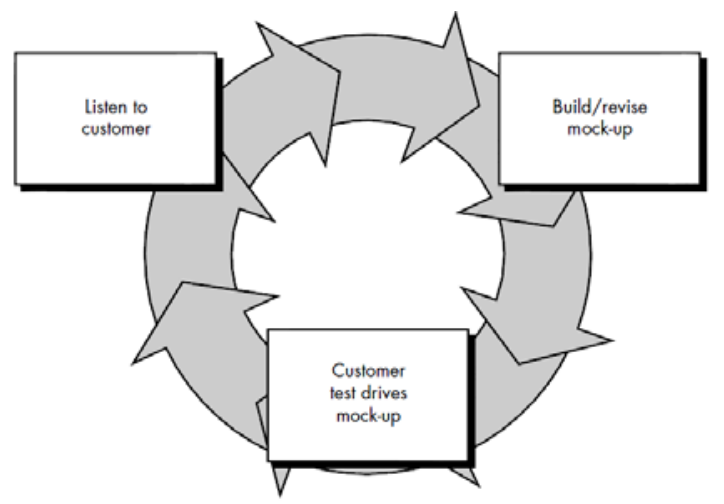

Gambar 2 Bagan Metode Prototype [7]

Gambar 2 tahapan metode prototype, diawali dengan listen-to-customer bertujuan untuk memperoleh informasi kebutuhan pengguna secara lengkap, antara lain alur proses, dan desain antarmuka. Desain alur proses dapat berupa usecase, activity diagram, class diagram, dan deployment diagram. Tahapan berikutnya adalah build/revise mock-up yaitu membangun aplikasi berdasarkan hasil tahap pertama secara cepat, dan aplikasi tersebut disebut sebagai prototip sampai menjadi aplikasi final. Tahap akhir metode prototype adalah customer test drives mock-up yaitu melakukan uji dan evaluasi prototip guna memperoleh info kekurangan ada pada prototip, jika dilakukan testing masih ada kekurangan, maka kembali pada tahap awal dan akan terus berlanjut hingga prototip menjadi aplikasi sesuai dengan kebutuhan pengguna. 
Desain sistem atau aplikasi penelitian ini menghasilkan sebuah usecase diagram yang berisi rancangan interaksi antara aktor dengan komponen atau modul sistem yang dibangun [8], hal itu ditunjukkan pada Gambar 3. Pada usecase diagram terlihat ada dua aktor aplikasi yaitu administrator dan user dari Dinas Pertanian Kota Salatiga. Aktor administrator dapat mengakses modul kelola user, kelola surat masuk, kelola surat keluar, kelola arsip, dan kelola forum. Administrator juga dapat mengirimkan notifikasi setelah melakukan pencatatan terhadap adanya surat masuk. Pegawai adalah aktor user, diijinkan untuk mengakses kelola profil pada aplikasi, melihat data arsip, dapat melakukan diskusi melalui forum yang tersedia dan mengelola data surat masuk dan keluar lewat fitur yang sudah disediakan.

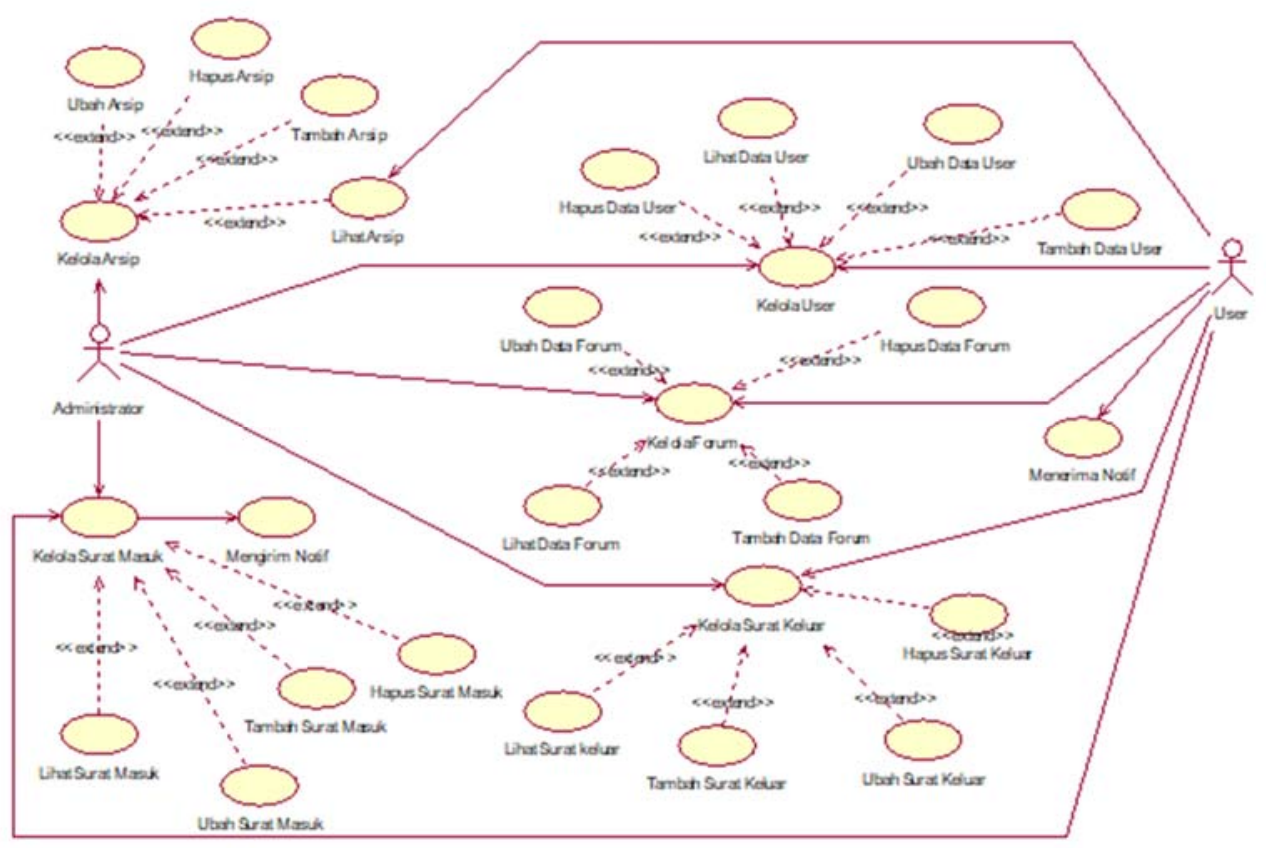

Gambar 3 Use Case Diagram Sistem Pengelolaan Surat

Activity diagram merupakan rancangan sistem atau aplikasi yang berisi desain alur proses aktivitas yang merupakan modul-modul yang terdapat pada desain usecase diagram, yang dilakukan oleh aktor aplikasi. Gambar 4 adalah activity diagram administrator dalam melakukan pengelolaan surat masuk, dimana diawali dengan membuka sistem yang dilanjutkan dengan sistem menampilkan halaman dimana pada halaman tersebut menampilkan dashboard dari aplikasi dan melakukan pemilihan menu untuk pengelolaan surat masuk, diteruskan dengan sistem menampilkan form entry surat masuk dimana pegawai meng-input-kan data keperluan surat yang akan tersimpan dalam database dan dilanjutkan dengan pegawai meng-input-kan data disposisi surat yang akan tersimpan dalam database. Setelah proses penyimpanan pada database selesai, sistem akan melakukan pengiriman notifikasi, alur pengelolaan surat tergambar seperti pada Gambar 4 . 
AITI: Jurnal Teknologi Informasi

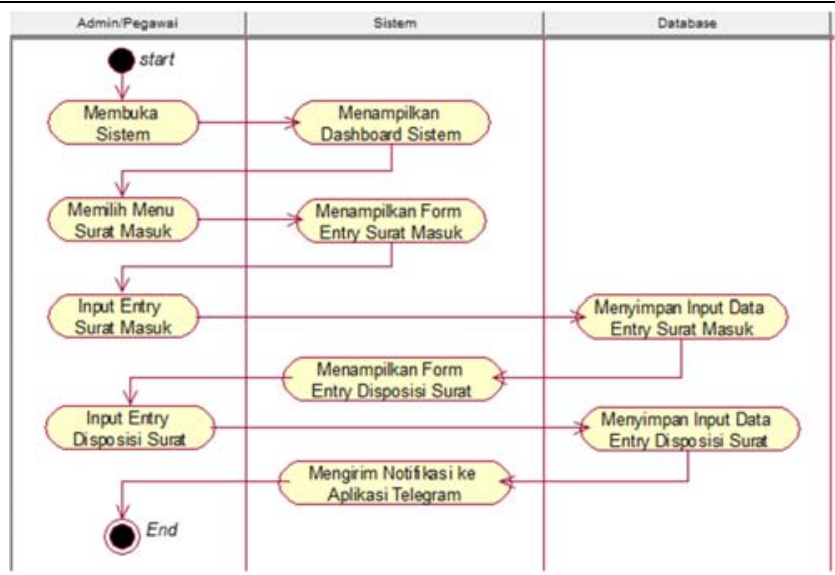

Gambar 4 Activity Diagram Administrator Kelola Surat Masuk

Pada activity diagram administrator kelola surat keluar menjelaskan proses alur sistem yang dirancang, pergerakan pada administrator Dinas Pertanian Kota Salatiga dalam mengirim atau melakukan pengelolaan terhadap surat keluar, diawali administrator membuka sistem yang dilanjutkan dengan sistem menampilkan halaman dimana pada halaman tersebut menampilkan dashboard dari aplikasi dan melakukan pemilihan menu untuk pengelolaan surat keluar, diteruskan dengan sistem menampilkan form entry surat keluar dimana pegawai meng-inputkan data keperluan surat yang akan tersimpan dalam database dan dilanjutkan dengan pegawai meng-input-kan data disposisi surat yang akan tersimpan dalam database. Alur pengelolaan surat tergambar seperti pada Gambar 5.

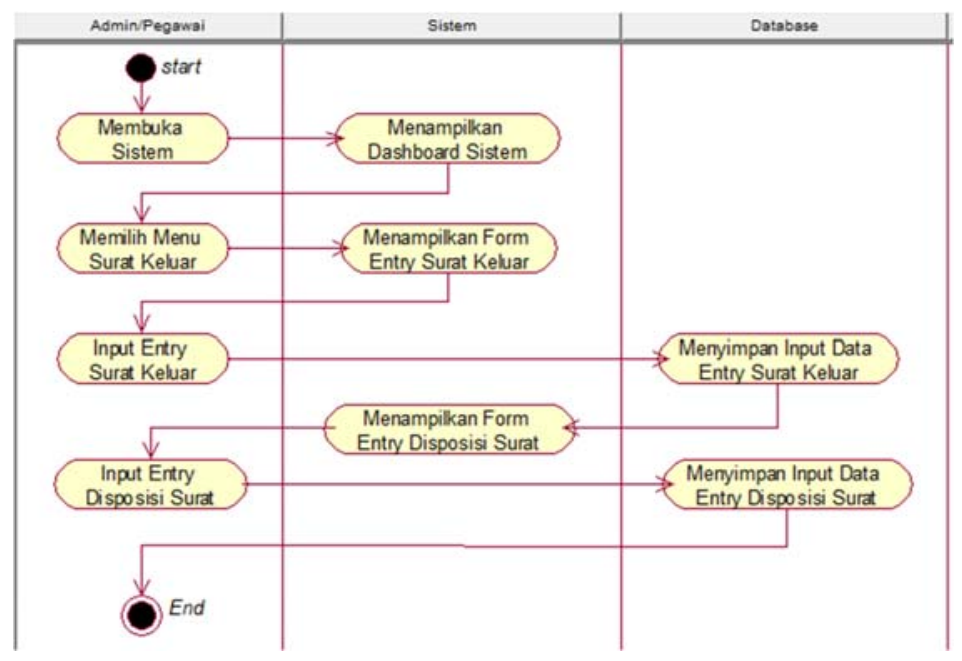

Gambar 5 Activity Diagram Administrator Kelola Surat Keluar

Activity diagram administrator kelola data arsip merupakan proses alur sistem pada aktor administrator Dinas Pertanian Kota Salatiga dalam melakukan pengelolaan data arsip, administrator membuka sistem yang dilanjutkan dengan sistem menampilkan halaman dimana pada halaman tersebut menampilkan dashboard dari aplikasi dan melakukan pemilihan menu untuk pengelolaan data 
arsip, diteruskan dengan sistem menampilkan seluruh data arsip dimana pegawai dapat melihat seluruh arsip yang ada, baik arsip surat masuk maupun surat keluar. Pada tampilan data arsip dimana admin memilih tab surat masuk ataupun tab surat keluar dapat dilakukan pengelolaan lebih lanjut seperti menambahkan arsip, menghapus, melihat dan memperbaharui arsip. Setelah admin/pegawai Dinas Pertanian dan Perikanan Kota Salatiga meng-input-kan data keperluan arsip yang akan dikelola lalu akan tersimpan dalam database dan dilanjutkan dengan sistem memberikan alert bahwa pengelolaan lebih lanjut pada arsip telah berhasil dilakukan. Alur pengelolaan data arsip surat masuk dan surat keluar tergambar seperti pada Gambar 6.

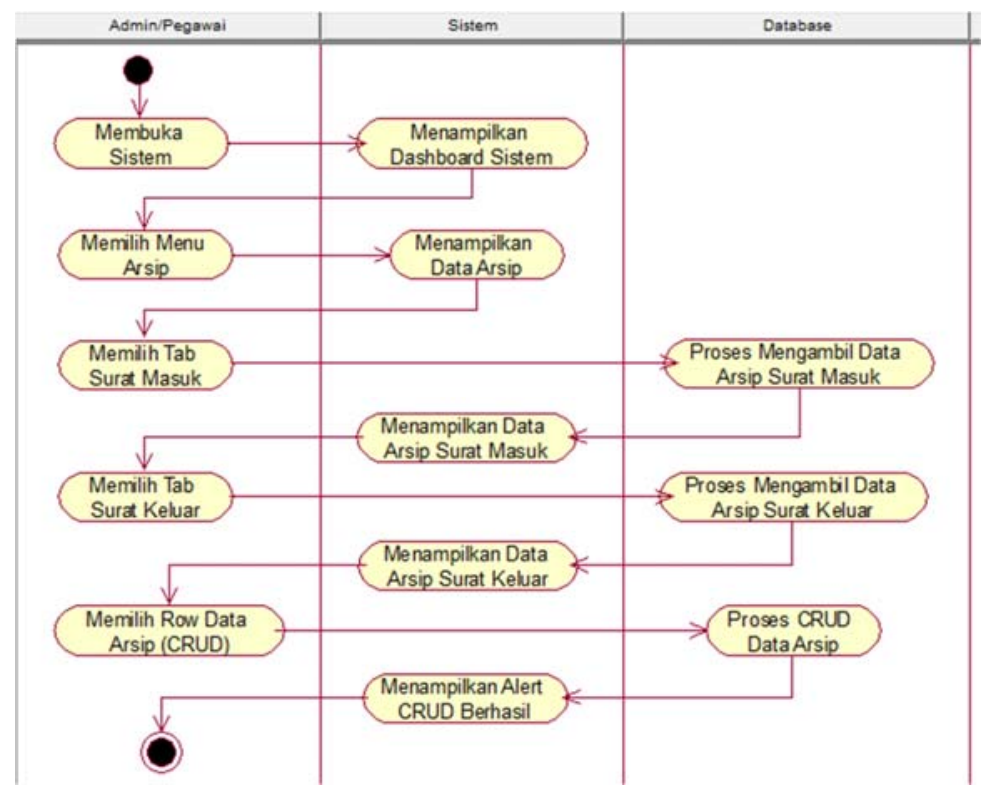

Gambar 6 Activity Diagram Administrator Kelola Data Arsip

Gambar 7 adalah deployment diagram, merupakan desain pemetaan dari bagian-bagian aplikasi yang akan dibangun, baik perangkat lunak maupun perangkat keras yang digunakan supaya aplikasi dapat running secara baik.

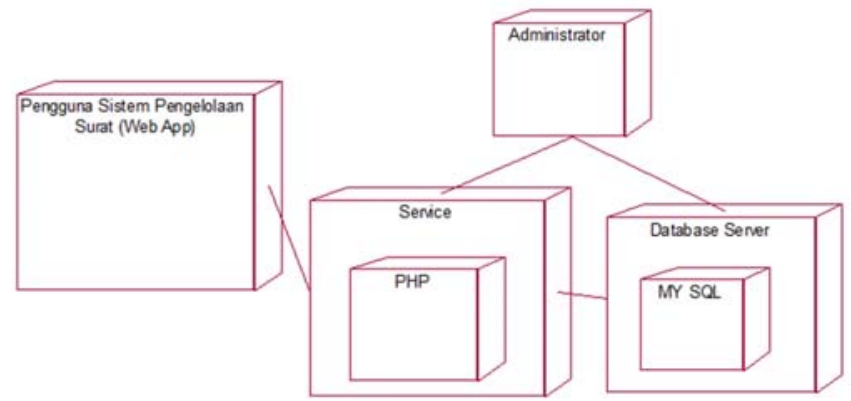

Gambar 7 Deployment Diagram Aplikasi 
AITI: Jurnal Teknologi Informasi

Volume 16 No. 2 Agustus 2019, 165-186

Sedangkan class diagram pada Gambar 8, merupakan desain yang menjelaskan interaksi antar entitas-entitas yang ada pada aplikasi, khususnya dalam basis data. Entitas yang berupa class dapat mewakili tabel yang beserta atribut yang menjelaskan tipe data tiap komponen-komponennya, serta beisi method yang dibutuhkan untuk mengakses atribut pada aplikasi yang dibangun.

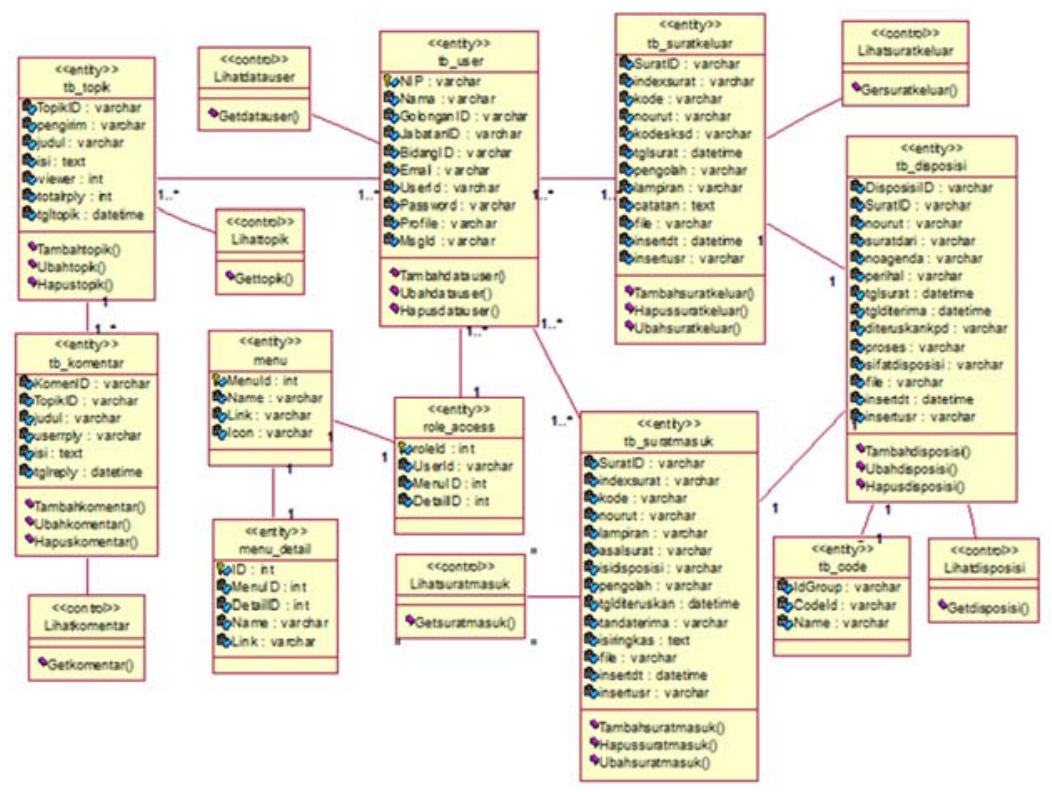

Gambar 8 Class Diagram

Pada Gambar 9 menggambarkan arsitektur dari sistem aplikasi yang dibangun. Sistem plikasi tersebut terdiri dari aplikasi website yang nantinya dapat digunakan oleh para pegawai Dinas Pertanian dan Perikanan Kota Salatiga. Sistem aplikasi tersebut harus terhubung dengan koneksi internet untuk dapat diakses melalui website. Internet akan dipergunakan untuk menjembatani aplikasi wbsite untuk mengirim data ke basis data yang disediakan oleh server melalui service PHP dan Application Programming Interface (API) dari aplikasi Telegram dalam platform mobile android sehingga semua pegawai Dinas dapat mengetahui tentang adanya surat yang masuk dan mengetahui adanya forum yang dibuat untuk segera didiskusikan dengan cara yang nantinya akan diberikan notifikasi ketika ada salah seorang pegawai yang melakukan pencatatan surat masuk atau pembuatan forum diskusi pada sistem atau aplikasi. 


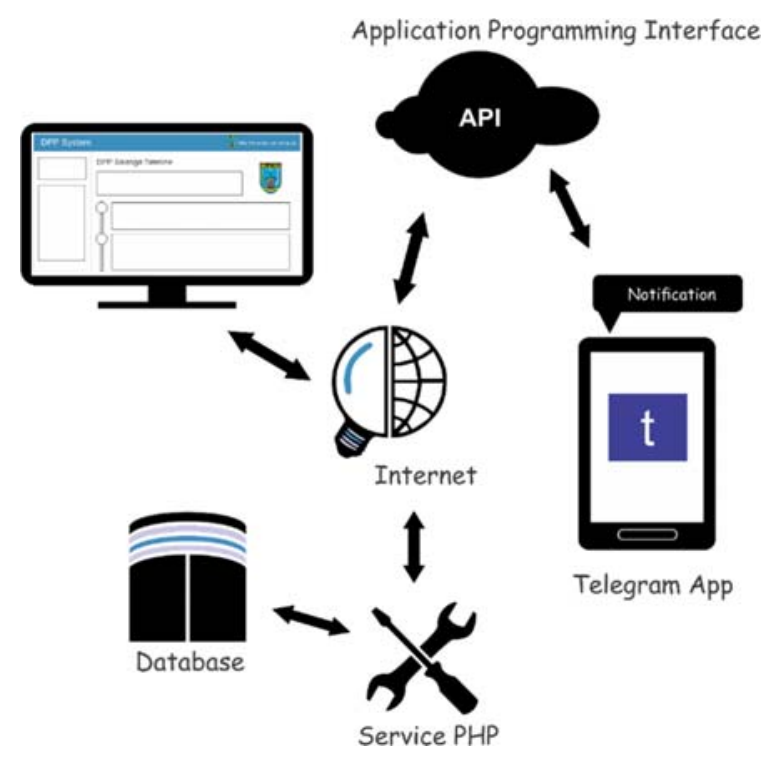

Gambar 9 Arsitektur Sistem

\section{Hasil dan Pembahasan}

Penelitian ini menghasilkan satu aplikasi yaitu aplikasi website. Aplikasi website ini ditujukan kepada pegawai Dinas Pertanian Kota Salatiga. Pegawai yg sebelumnya masih memakai sistem manual pada pengelolaan surat masuk dan keluar serta tidak memiliki pemberitahuan tentang surat yang harus segera diproses untuk mengingatkan kapan waktunya tiba melakukan tindak lanjut pada pada surat yang masuk dan juga Kepala Dinas dapat melihat kinerja dari semua pegawai yang bekerja pada Dinas Pertanian dan Perikanan Kota Salatiga. Pada aplikasi ini saat pegawai membuka website akan ditujukan halaman login agar dapat mengetahui siapa yang melakukan pekerjaan dengan baik atau tidak. Gambar 10 menunjukkan form login digunakan sebagai keamanan dasar pada sistem dari penyalahgunaan hak akses, sehingga keamanan data dapat terjamin. Pada proses login user diminta untuk memasukkan username dan password untuk dapat mengakses data selanjutnya.

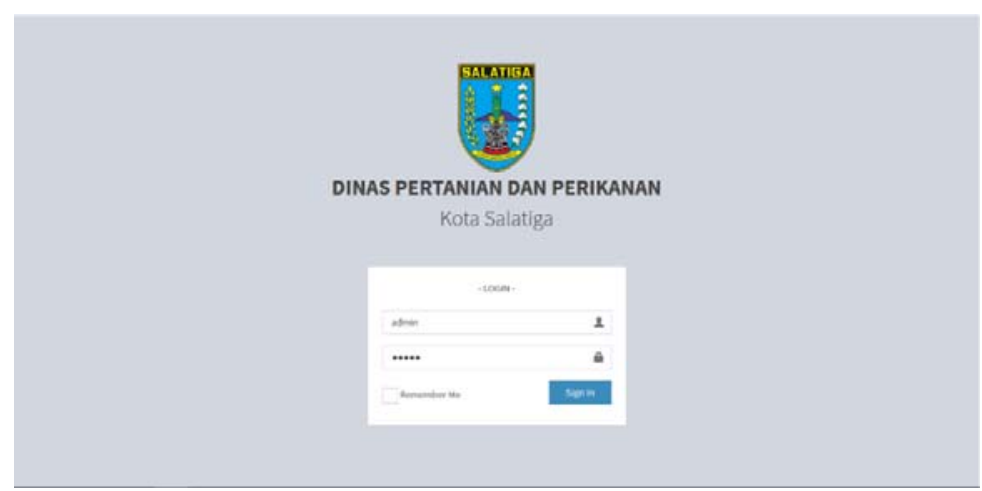

Gambar 10 Tampilan Form Login 
AITI: Jurnal Teknologi Informasi

Volume 16 No. 2 Agustus 2019, 165-186

Kode Program 1. Proses Login Sistem

01. function $\operatorname{login}()\{$

02. \$user $=\$$ this->input->post $\left(\right.$ 'user' $\left.^{\prime}\right)$;

03. $\$$ pass $=$ \$this->input $->$ post $\left(\right.$ 'pass' $\left.^{\prime}\right)$;

04. if (\$this->DataModel->ceklogin(\$user, \$pass)) \{

05. redirect ('Admin/index', 'refresh');\}else\{

06. redirect ('MainController/index', 'refresh');\}\}

Kode program 1 merupakan struktur source code/pemrograman yang dilakukan untuk melakukan login pada sistem pengelolaan surat. Ketika kode program dari baris 2 dan 3 di eksekusi maka akan mengambi data input dari form yang ada pada halaman login. Setelah proses 2 dan 3 terpenuhi maka akan diteruskan pada baris 4 yang melakukan eksekusi pada function cek login yang berada pada data model dengan melemparkan value berupa username dan password. Proses terakhir pada login sistem dilakukan pada proses baris 5 dan 6 yang melakukan pemanggilan page index bila dalam pengecekan username dan password berhasil.

Gambar 11 merupakan tampilan utama dari system Dinas Pertanian Kota Salatiga yang isinya dashboard, arsip, surat masuk, surat keluar dan user management. Pengguna sistem aplikasi tinggal klik saja icon menu yang di inginkan untuk melihat apa saja yang ada di dalam file tersebut.

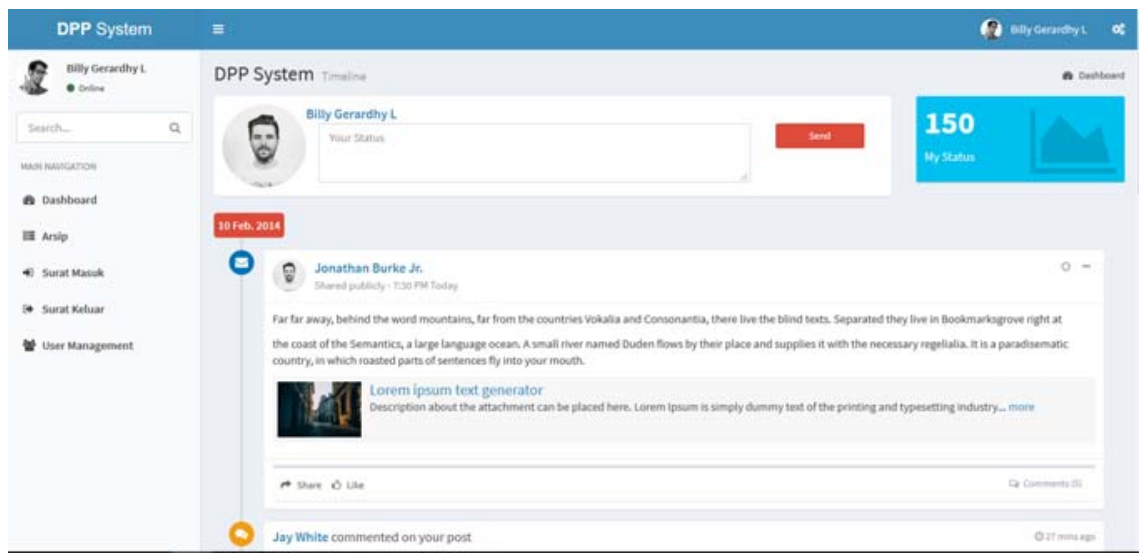

Gambar 11 Tampilan Dashboard Sistem 


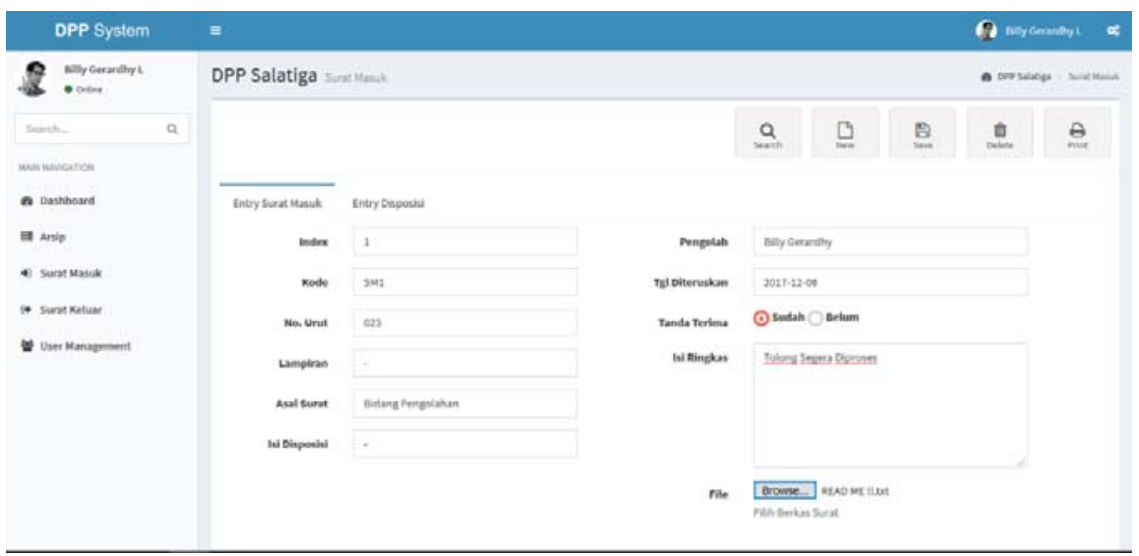

Gambar 12 Tampilan Input Surat Masuk

Pada Gambar 12 merupakan menu surat masuk yang merupakan halaman dimana user dapat menginput data surat masuk. Dimana didalamnya berisikan index surat, kode surat, nomor urut surat, lampiran, asal surat, isi disposisi surat, pengolah, tanggal diteruskan surat, tanda terima surat, isi rungkas dan attachment surat dan setelah selesai penginputan klik tombol save dan akan diteruskan pada pengisian disposisi surat masuk.

Pada Gambar 13 merupakan Menu input disposisi surat masuk yang merupakan halaman dimana user dapat menginput data disposisi dari surat masuk. Dimana didalamnya berisikan nomor surat, surat dari, no. agenda, tanggal surat, diterima tanggal, perihal, diteruskan kepada, dengan hormat harap, sifat disposisi dan attachment surat, setelah selesai penginputan klik tombol save maka data akan tersimpan pada database lebih jelasnya seperti tampilan dibawah ini.

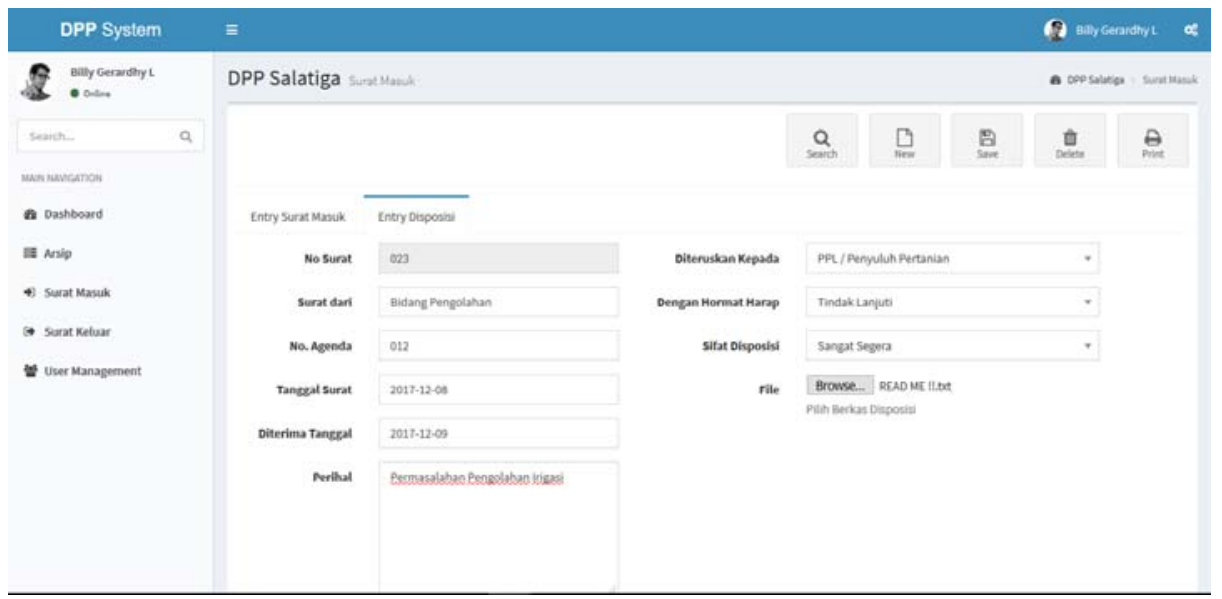

Gambar 13 Tampilan Input Disposisi Surat Masuk

Kode Program 2. Proses Simpan Surat Masuk dan Disposisi

01. function savedata ( $\$$ index $=$ \$this->input->post ('index'); \$kode = \$this->input>post ('kode');

02. \$nourut $=$ \$this->input->post ('nourut'):

03. \$lampiran = \$this->input->post('lampiran'); 
AITI: Jurnal Teknologi Informasi

04. $\$$ asal $=$ \$this->input->post ('asal' $) ; \ldots)\{$

05. \$surat = array ("SuratID" => \$SuratID ", "indexsurat" =>

06. \$index, "kode" => \$kode, "nourut" => \$nourut,

07. "lampiran" => \$lampiran, "asalsurat" => \$asal ,

๑8. "isidisposisi" $=>$ \$isidisposisi , ...)

09. \$this->SMModel->insertsurat (\$surat);

10. \$this->SMModel->insertdispo(\$disposisi);

11. \$this->notif(\$SuratID);

Kode program 2 merupakan struktur source code / pemrograman yang dilakukan untuk melakukan proses penginputan surat masuk dan disposisi surat masuk pada sistem pengelolaan surat. Ketika kode program dari baris 2 - 9 di eksekusi maka akan mengambi data input dari form yang ada pada halaman surat masuk dan juga disposisi surat. Setelah proses 2 - 9 terpenuhi maka akan diteruskan pada baris 10 yang melakukan eksekusi pada function insertsurat yang berada pada data model dengan melemparkan value berupa data array surat. Pada baris 11 melakukan eksekusi pada function insertdispo yang berada pada data model dengan melemparkan value berupa data array disposisi. Proses terakhir pada proses insert data surat masuk dan disposisi surat masuk terdapat pada baris 12 yang melakukan pemanggilan pada function notif, dimana function ini melakukan pengiriman sebuah notifikasi kepada pegawai melalui aplikasi telegram.

Pada Gambar 14 merupakan tampilan menu surat keluar yang merupakan halaman dimana user dapat menginput data surat yang akan keluar. Dimana didalamnya berisikan index surat, kode surat, nomor urut surat, no. kode SKSD, tanggal surat, pengolah, lampiran dan attachment surat dan setelah selesai penginputan klik tombol save dan akan diteruskan pada pengisian disposisi surat keluar.

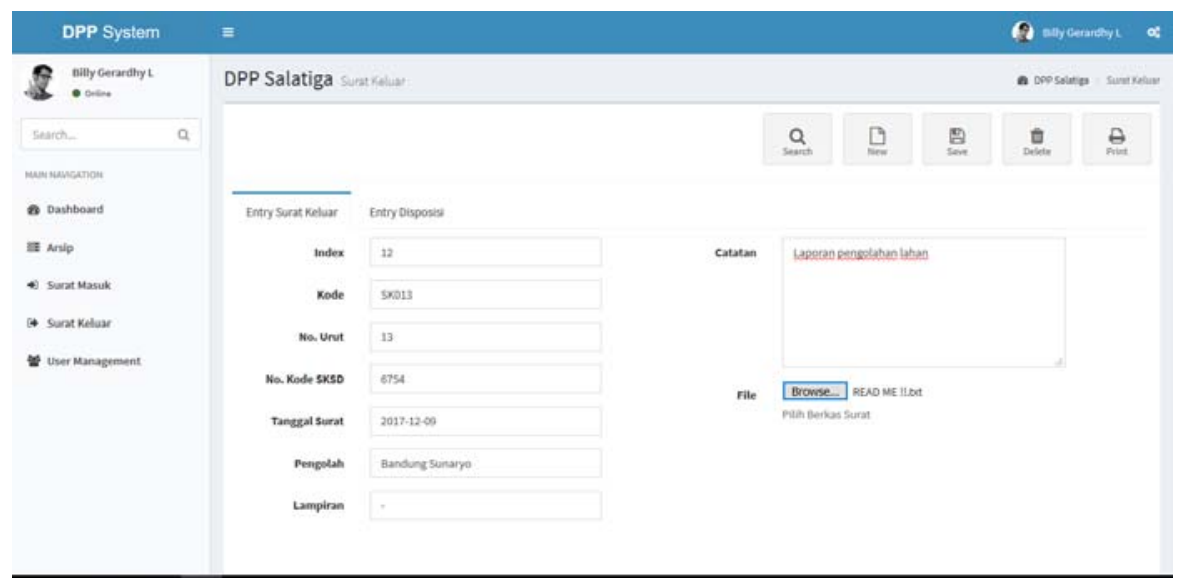

Gambar 14 Tampilan Input Surat Keluar

Kode Program 3. Proses Simpan Surat Keluar

01. function tbSave $(x)\{$ if $(x==1)\{\$($ "\#upload1"

०2. ). submit( ); var file1 $=\$(" \#$ file1"). val(). replace (

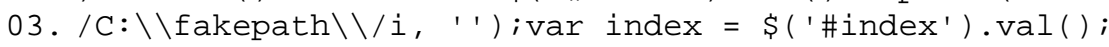

04. $\operatorname{var}$ kode $=\$($ '\#kode') $\operatorname{val}() ; \operatorname{var}$ kodesksd =

๑5. \$('\#kodesksd') $\cdot \operatorname{val}() ; \operatorname{var}$ nourut $=\$($ '\#nourut') $\cdot \operatorname{val}()$;

06. \$.post ( '<?php echo 
07. site_url('SK/savedata') ?>',\{file1:file1, index:index,

๑8. kode: kode, kodesksd: kodesksd, ...

๑9. function(data) $\{$ alert (data); $\})$; \}else if $(x==2)\{$

10. no_event ( ) ; \}else \{

11. no_event ()$;\}$

12. $\}$

Kode program 3 merupakan struktur source code / pemrograman yang dilakukan untuk melakukan proses penginputan surat keluarpada sistem pengelolaan surat. Ketika kode program dari baris 2 - 5 di eksekusi maka akan mengambi data input dari form yang ada pada halaman surat keluar. Setelah proses 2 - 5 terpenuhi maka akan diteruskan pada baris 6 - 8 yang melakukan eksekusi pada function insertsurat yang berada pada data model dengan melemparkan value berupa data array surat. Proses terakhir pada proses insert data surat keluar terdapat pada baris 9 yang melakukan pemanggilan pada dimana function ini memberikan sebuah alert bahwa dan menampilkan pop-up detail surat kepada pegawai.

Pada Gambar 15 dan 16 merupakan tampilan menu arsip yang merupakan halaman dimana user dapat melihat data surat masuk yang telah diinputkan oleh user. Dimana didalamnya berisikan data dari surat yang telah selesai dilakukan penginputan. Pada sebelah kolom isi ringkasan terdapat sebuah tombol yang akan menampilkan detail dari surat masuk.

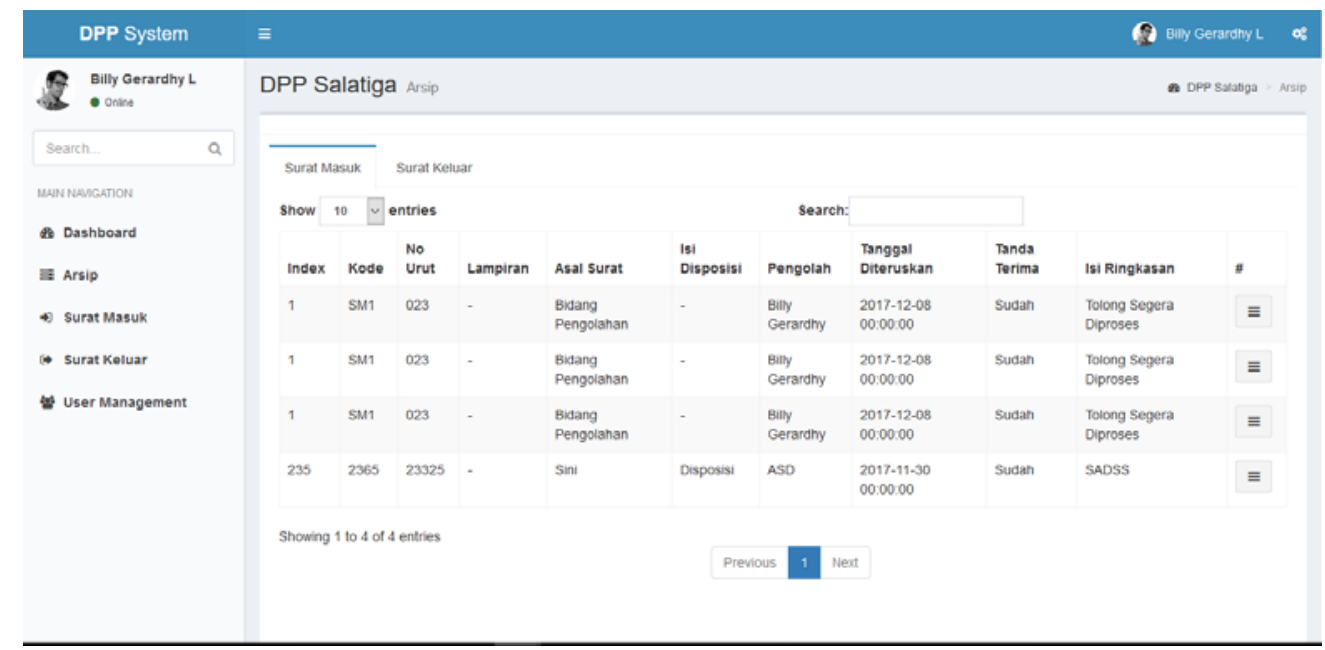

Gambar 15 Tampilan Arsip Surat Masuk 


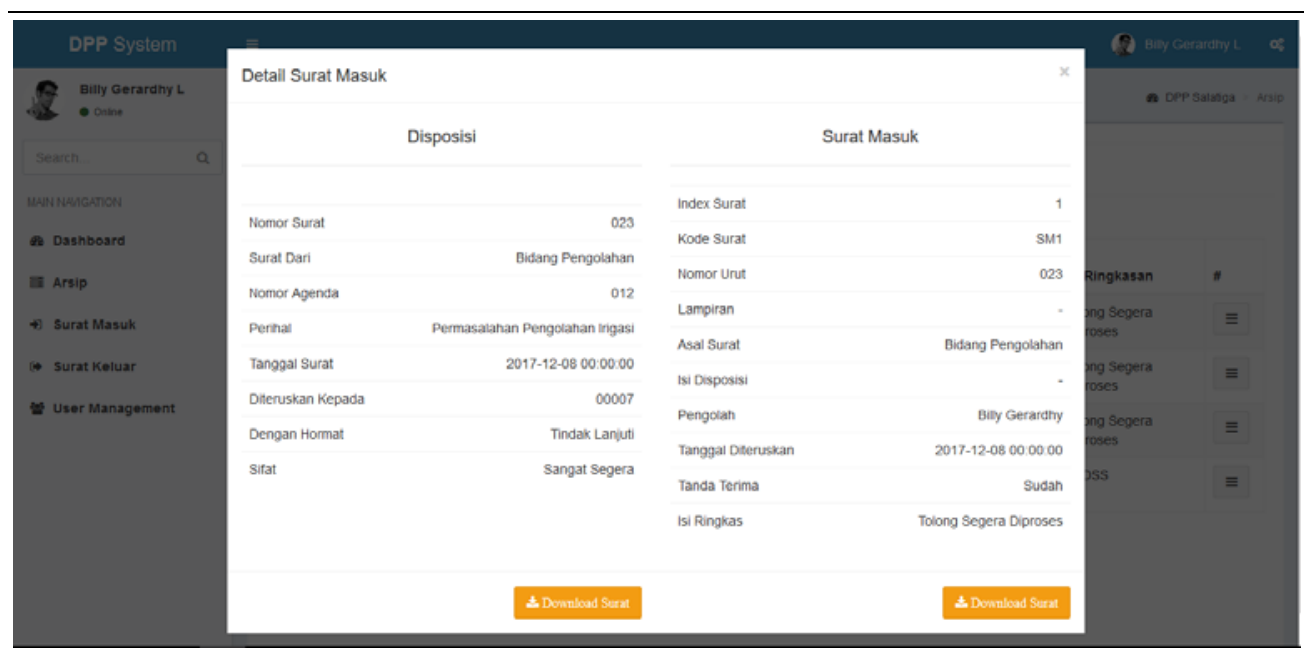

Gambar 16 Tampilan Detail Arsip Surat Masuk

Kode Program 4. Proses Detail Surat Masuk dan Download File

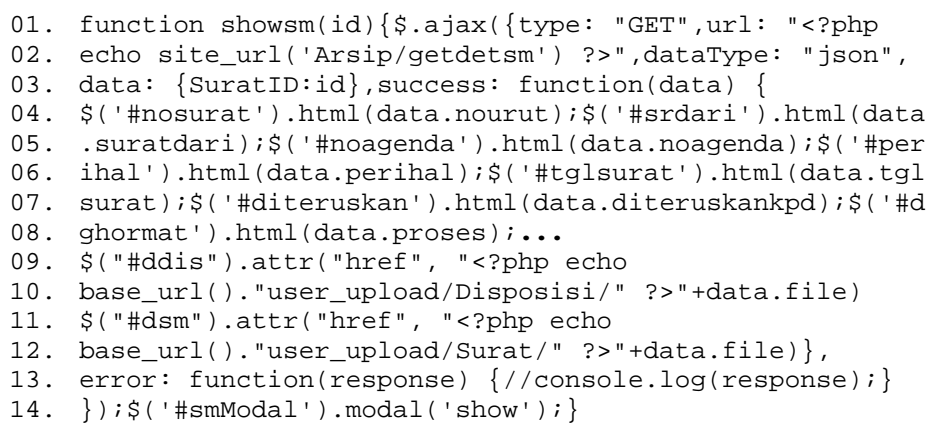

Kode program 4 merupakan struktur source code / pemrograman yang dilakukan untuk melakukan proses pemanggilan data surat masuk dan disposisi surat masuk pada sistem pengelolaan surat. Ketika kode program dari baris 1 - 3 di eksekusi maka akan mengambi data input dari database dengan melakukan pemanggilan function getdetsm untuk surat masuk dan juga disposisi surat. Setelah proses 1 - 3 terpenuhi maka akan diteruskan pada baris 4 - 8 yang melakukan penampungan data dari database surat masuk dan disposisi surat. Pada baris 9 dan 11 melakukan eksekusi untuk melakukan proses download file surat masuk dan file disposisi surat. Proses terakhir pada proses lihat detail data surat masuk dan disposisi surat masuk terdapat pada baris 13 dan 14 yang melakukan pemanggilan pada function respon, dimana function ini memberikan sebuah alert bahwa dan menampilkan pop-up detail surat kepada pegawai.

Pada Gambar 17 dan 18 merupakan tampilan menu arsip surat keluar yang merupakan halaman dimana user dapat melihat data surat keluar yang telah diinputkan oleh user. Dimana didalamnya berisikan data dari surat yang telah selesai dilakukan penginputan. Pada sebelah kolom isi ringkasan terdapat sebuah tombol yang akan menampilkan detail dari surat keluar. 


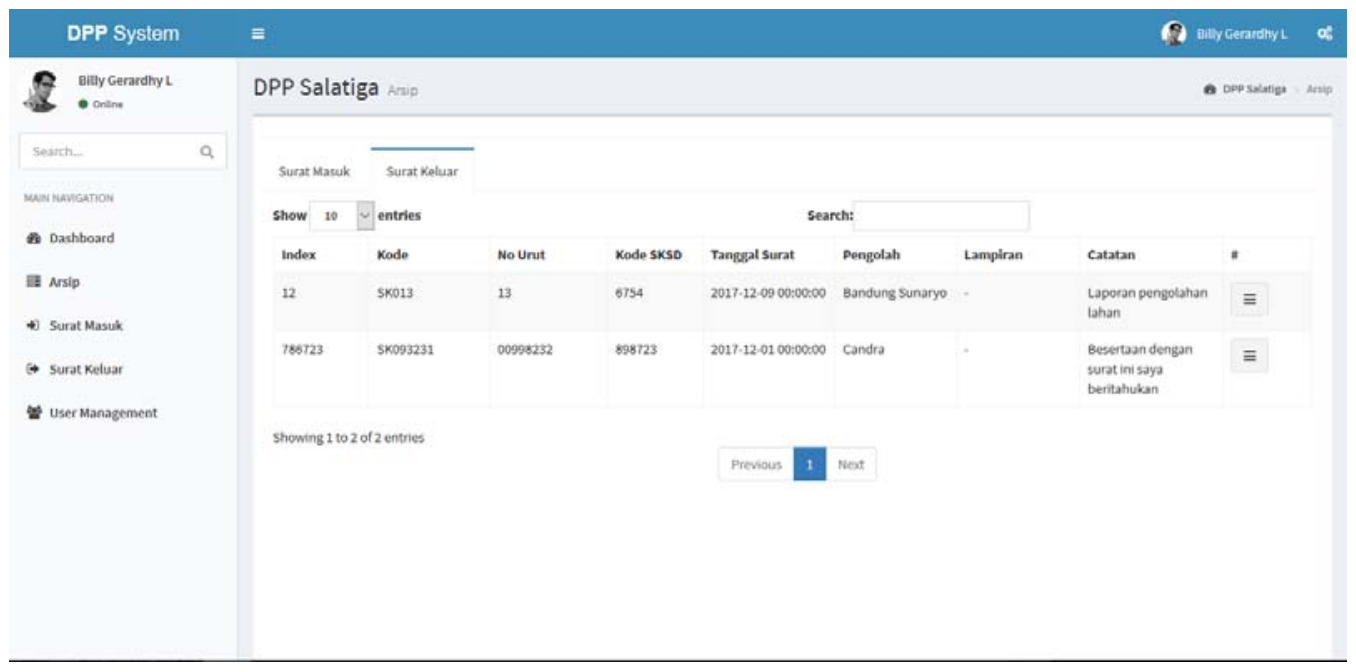

Gambar 17 Tampilan Arsip Surat Keluar

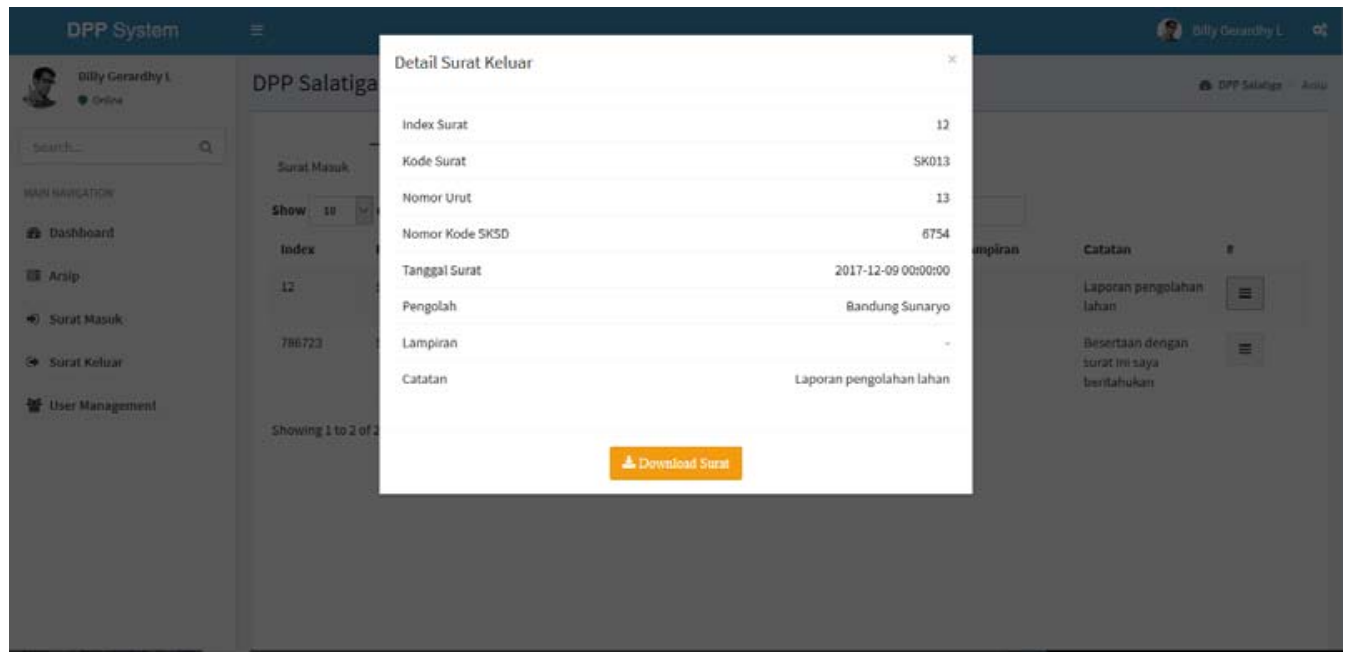

Gambar 18 Tampilan Detail Arsip Surat Keluar

Kode Program 5. Proses Detail Surat Keluar dan Download File

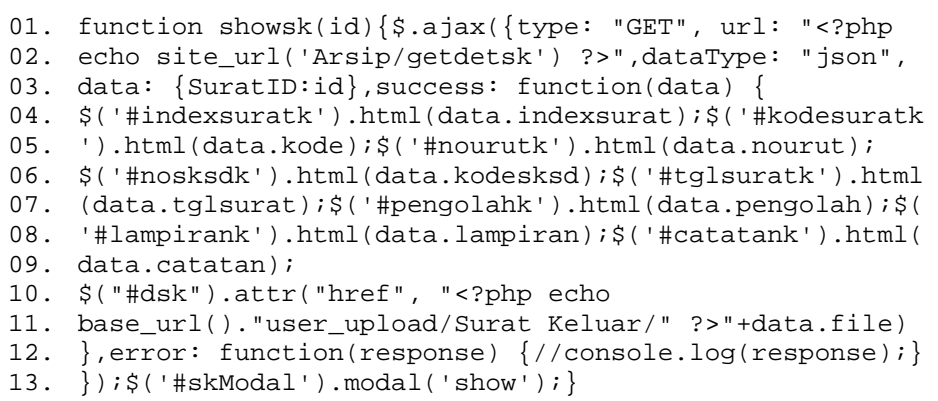

Kode program 5 merupakan struktur source code / pemrograman yang dilakukan untuk melakukan proses pemanggilan data surat masuk dan disposisi surat masuk pada sistem pengelolaan surat. Ketika kode program dari baris 1 - 3 di eksekusi maka akan mengambi data input dari database dengan melakukan 
AITI: Jurnal Teknologi Informasi

Volume 16 No. 2 Agustus 2019, 165-186

pemanggilan function getdetsk untuk surat keluar dan juga disposisi surat. Setelah proses 1 - 3 terpenuhi maka akan diteruskan pada baris 4 - 9 yang melakukan penampungan data dari database surat keluar dan disposisi surat. Pada baris 10 melakukan eksekusi untuk melakukan proses download file surat masuk dan file disposisi surat. Proses terakhir pada proses lihat detail data surat masuk dan disposisi surat masuk terdapat pada baris 12 dan 13 yang melakukan pemanggilan pada function respon, dimana function ini memberikan sebuah alert bahwa dan menampilkan pop-up detail surat kepada pegawai.

Pada Gambar 19 dan 20 merupakan tampilan menu user management yang merupakan halaman dimana user dapat melakukan manajemen terhadap user yang akan memakai sistem aplikasi pengolahan surat. Dimana didalamnya berisikan data dari pegawai dan juga hak akses dari pegawai tersebut. Pada sebelah kolom username terdapat beberapa tombol yang akan digunakan untuk melakukan pengolahan terhadap data user.

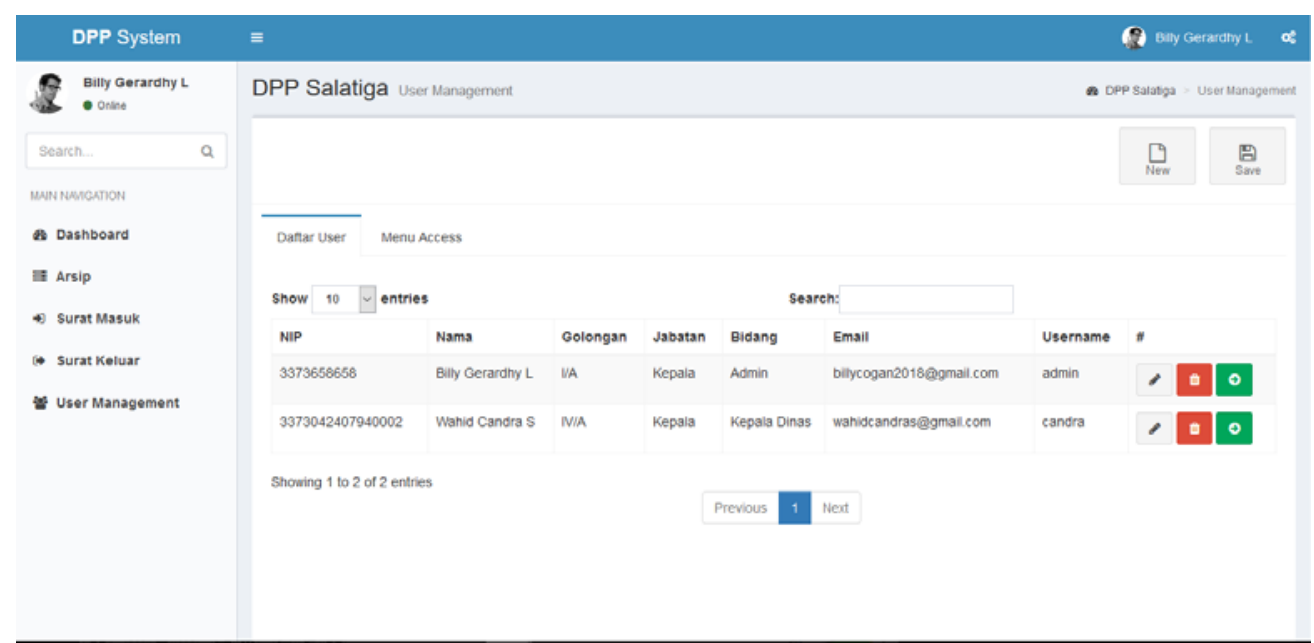

Gambar 19 Tampilan User Management

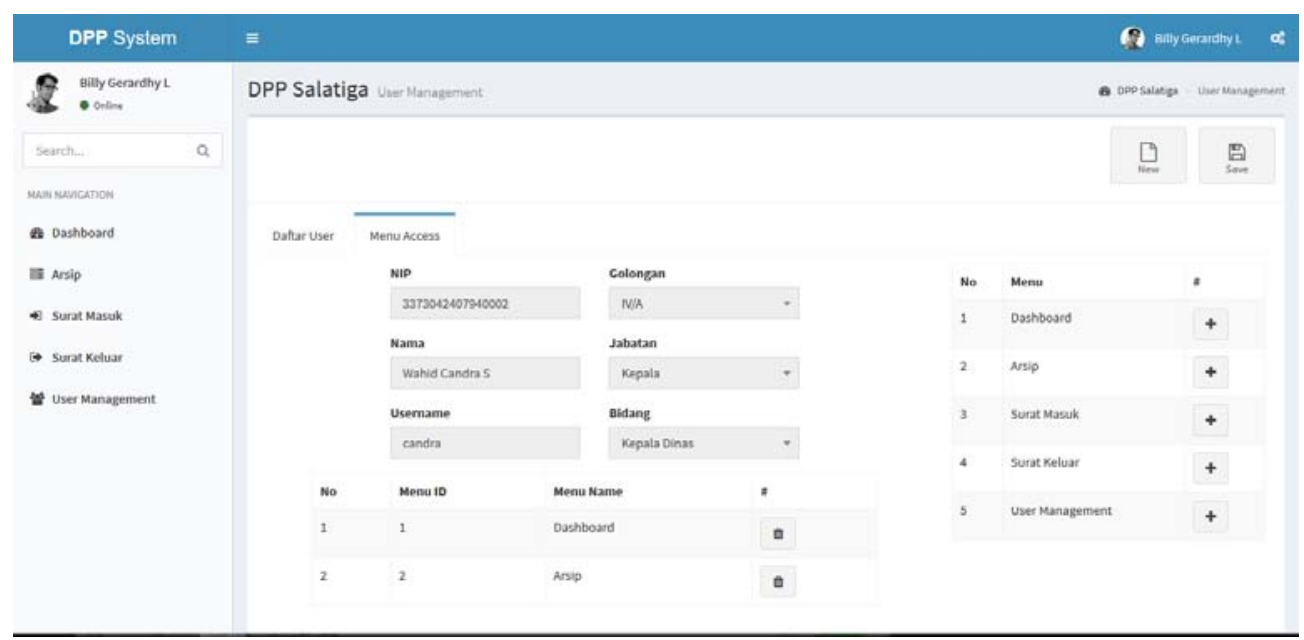

Gambar 20 Tampilan User Management 
Pada aplikasi telegram yang terdapat pada smartphone, pegawai diwajibkan melakukan login pada DPPSalatiga Bot syatem, agar dapat mendapatkan notifikasi realtime dari proses pengelolaan surat. Gambar 21 menunjukkan form login digunakan sebagai keamanan dasar pada sistem dari penyalahgunaan hak akses, sehingga keamanan data dapat terjamin. Pada proses login user diminta untuk memasukkan username dan password untuk dapat mengakses data selanjutnya.

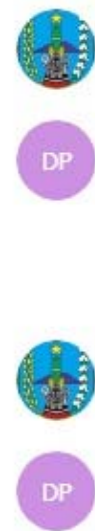

/start

DPPSalatiga

Selamat Datang di Sistem Notifikasi Dinas Pertanian dan Perikanan Kota Salatiga. Silahkan Masukkan Username dan Password Anda untuk mendapatkan notifikasi melalui Telegram dengan format : LOGIN_Username_Password

Admin

LOGIN_admin_admin

DPPSalatiga

Selamat Akun Telegram anda telah terhubung dengan Sistem DPP Salatiga.

Gambar 21 Tampilan DPPSalatiga Bot system

Kode Program 6. Proses Login pada Telegram App

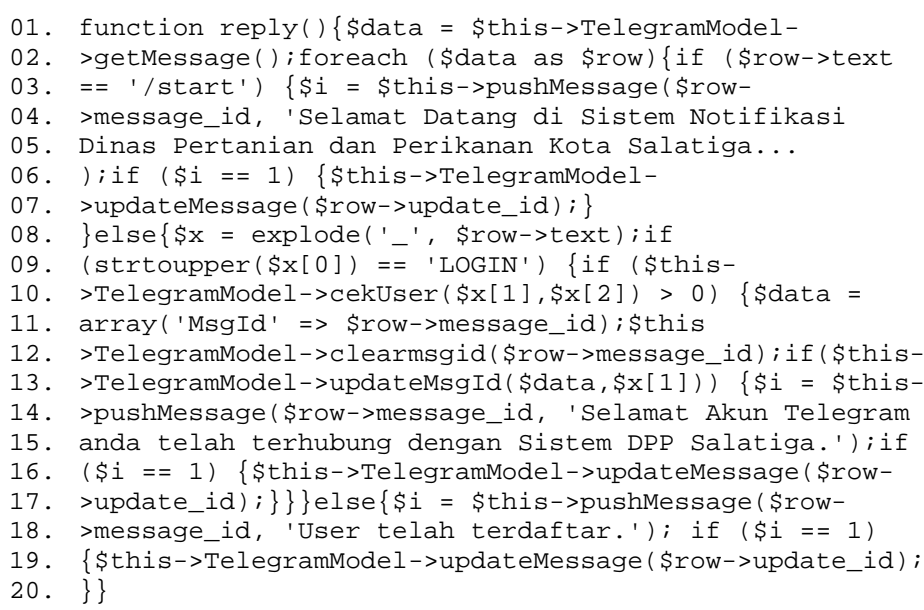

Kode program 6 merupakan struktur source code / pemrograman yang dilakukan untuk melakukan proses login pada sistem pengelolaan surat yang ada pada aplikasi telegram. Ketika kode program dari baris 1 - 7 di eksekusi maka sistem akan melakukan perulangan dan memulai proses start dari layanan yang diberikan oleh API dari telegram dan menampilkan ucapan selamat datang dan permintaan melakukan login kepada pegawai. Setelah proses 1 - 7 terpenuhi maka 
AITI: Jurnal Teknologi Informasi

akan diteruskan pada baris 8 - 17 yang melakukan pengecekan terhadap username dan password yang diinputkan oleh pegawai dari database user. Pada baris $18-20$ mengeksekusi bila ternyata user benar sudah terdaftar pada DPPSalatiga Bot System.

Pada Gambar 22 merupakan tampilan aplikasi telegram yang terdapat pada smartphone, pegawai diwajibkan mendapatkan sebuah notifikasi secara realtime pada DPPSalatiga Bot syatem bila terdapat surat masuk dan disposisi surat setelah pegawai selesai melakukan penginputan., agar pegawai yang ditujukan dapat segera melakukan proses pada surat masuk tersebut.

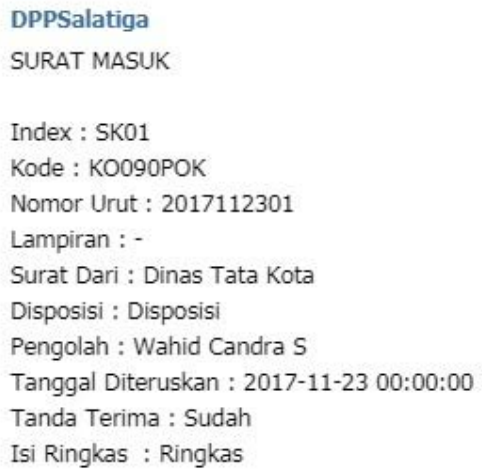

Gambar 22 Tampilan DPPSalatiga Bot system

Kode Program 7. Proses Detail Notifikasi Telegram App

01. public function pushMessage (\$chat_id, \$text) $\{\$$ key $=$

02. "470154184: AAFMdQnDhUNChYOGX4MSvnj4fqkkHei3-bg"; \$host

03. = "https://api.telegram.org/bot".\$key.'/';

04. \$send =file_get_contents(\$host. "sendmessage?chat_id="

05. . \$chat_id."\&\&text=". \$text);

06. \$result $=$ json_decode $(\$$ send $)$; return \$result->ok; $\}$

07. function notif(\$suratID, \$diteruskan) $\{$ surat $=\$$ this -

08. >SMModel->getsurat (\$suratID); \$msgid = \$this-

09. >TelegramModel->getmsgid(\$diteruskan); foreach (\$msgid

10. as \$row) \{echo \$row->MsgId; \$message = "SURAT

11. MASUK \n\nIndex : ".\$surat->indexsurat."\nKode :

12. ". \$surat->kode." \nNomor Urut : ".\$surat-

13. >nourut." \nLampiran : ".\$surat->lampiran."\nSurat Dari

14.: ".\$surat->asalsurat."\nDisposisi : ".\$surat-

15. >isidisposisi."\nPengolah : ". \$surat-

16. >pengolah. "\nTanggal Diteruskan : ".date ('d-m-

17. $Y^{\prime}$, strtotime(\$surat->tglditeruskan)). "\nTanda Terima :

18. ". \$surat->tandaterima." \nIsi Ringkas : ".\$surat-

19. >isiringkas. "\n"; \$this->pushMessage(\$row-

20. >MsgId, urlencode(\$message) ); \} 
Kode program 7 merupakan struktur source code / pemrograman untuk menampilkan isi dari notifikasi yang diterima oleh pegawai yang ditujukan bila telah dilakukan penginputan surat masuk dan disposisi surat pada sistem pengelolaan surat yang ada pada aplikasi telegram. Kode program dari baris 1 - 6 di eksekusi maka sistem akan melakukan pengecekan terhadap key dari layanan yang diberikan oleh API dari telegram agar dapat mendapatkan notifikasi pada aplikasi telegram. Setelah proses 1 - 6 terpenuhi maka akan diteruskan pada baris 7 - 20 yang melakukan pemanggilan function getsurat dan melakukan penampungan data surat yang akan ditampilkan pada aplikasi telegram DPPSalatiga Bot System.

Pengujian aplikasi adalah tahapan pada penelitian yang bertujuan untuk mendapatkan bukti bahwa aplikasi yang dihasilkan telah sesuai yang diharapkan dan memenuhi kebutuhan dari pengguna aplikasi. Pengujian aplikasi menggunakan metode blackbox yaitu dilakukan dengan menguji seluruh fungsi dan fitur yang dimiliki aplikasi. Pengujian ini dilakukan guna memastikan bahwa sudah tidak ada kesalahan/bug pada sistem dan segala modul proses dan fungsi sistem yang dibuat telah berjalan sesuai rancangan. Tabel 1 merupakan hasil pengujian blackbox.

Tabel 1 Hasil Pengujian Blackbox

\begin{tabular}{|c|c|c|c|c|}
\hline $\begin{array}{c}\text { Fungsi yang } \\
\text { diuji }\end{array}$ & Kondisi & $\begin{array}{l}\text { Output yang } \\
\text { diharapkan }\end{array}$ & $\begin{array}{c}\text { Output yang } \\
\text { dihasilkan } \\
\text { sistem }\end{array}$ & $\begin{array}{c}\text { Status } \\
\text { Pengujian }\end{array}$ \\
\hline Login & $\begin{array}{lr}\text { Mengisi } & \text { form } \\
\text { Email } & \text { dan } \\
\text { Password } & \text { dengan } \\
\text { benar } & \end{array}$ & Berhasil Login & Sukses Login & Valid \\
\hline \multirow{3}{*}{$\begin{array}{l}\text { Input data } \\
\text { surat masuk } \\
\text { Input data } \\
\text { surat keluar }\end{array}$} & $\begin{array}{l}\text { Form diisi dengan } \\
\text { benar }\end{array}$ & $\begin{array}{l}\text { Sukses } \\
\text { data }\end{array}$ & $\begin{array}{l}\text { Sukses } \\
\text { data }\end{array}$ & Valid \\
\hline & $\begin{array}{l}\text { Form diisi dengan } \\
\text { benar }\end{array}$ & $\begin{array}{l}\text { Sukses insert } \\
\text { data }\end{array}$ & $\begin{array}{l}\text { Sukses } \\
\text { data }\end{array}$ & Valid \\
\hline & $\begin{array}{ll}\text { Form } & \text { diisi } \\
\text { beberapa } & \text { atau } \\
\text { kosong } & \end{array}$ & $\begin{array}{l}\text { Gagal tambah } \\
\text { data }\end{array}$ & $\begin{array}{l}\text { Gagal } \\
\text { data }\end{array}$ & Valid \\
\hline $\begin{array}{l}\text { Managemen } \\
\text { acess user }\end{array}$ & $\begin{array}{l}\text { Pemberian hak } \\
\text { akses page sistem } \\
\text { pengelolaan surat }\end{array}$ & $\begin{array}{l}\text { Sukses } \\
\text { memeberikan } \\
\text { hak akses }\end{array}$ & $\begin{array}{l}\text { Sukses } \\
\text { memberikan hak } \\
\text { akses }\end{array}$ & Valid \\
\hline \multirow[t]{2}{*}{$\begin{array}{l}\text { Notifikasi } \\
\text { API } \\
\text { Telegram }\end{array}$} & $\begin{array}{l}\text { Surat masuk dan } \\
\text { Disposisi surat } \\
\text { berhasil tersimpan } \\
\text { pada database }\end{array}$ & $\begin{array}{lr}\text { Sukses } & \text { kirim } \\
\text { pesan } & \text { dan } \\
\text { tampilkan } & \\
\text { notifikasi } & \end{array}$ & $\begin{array}{lr}\text { Sukses } & \text { kirim } \\
\text { pesan } & \text { dan } \\
\text { tampilkan } & \\
\text { notifikasi } & \end{array}$ & Valid \\
\hline & $\begin{array}{lr}\text { Surat masuk dan } \\
\text { Disposisi surat } \\
\text { tanpa diteruskan } \\
\text { kepada berhasil } \\
\begin{array}{lr}\text { tersimpan } \\
\text { database }\end{array}\end{array}$ & $\begin{array}{lr}\text { Gagal } & \text { kirim } \\
\text { pesan } & \text { dan } \\
\text { notifikasi } & \end{array}$ & $\begin{array}{lr}\text { Gagal } & \text { kirim } \\
\text { pesan } & \text { dan } \\
\text { notifikasi } & \end{array}$ & Valid \\
\hline
\end{tabular}


AITI: Jurnal Teknologi Informasi

Volume 16 No. 2 Agustus 2019, 165-186

Pengujian lain yang dilakukan pada aplikasi yaitu acceptance test yang dilakukan oleh pengguna di Dinas Peranian Kota Salatiga. Pada pengujian ini menggunakan media kuisioner guna mengetahui dampak langsung dari penggunaan aplikasi terhadap proses pengelolaan surat dan efektivitas kerja, dan hasilnya dapat terlihat pada Tabel 2.

Tabel 2 Perbedaan Proses Bisnis via Website

\begin{tabular}{|c|c|c|c|}
\hline .No & SOP Lama & SOP Baru & Perbedaan \\
\hline 1. & $\begin{array}{l}\text { Pegawai tidak memiliki } \\
\text { notifikasi adanya surat } \\
\text { masuk }\end{array}$ & $\begin{array}{l}\text { Diberikan notifikasi pada } \\
\text { aplikasi Telegram bahwa } \\
\text { adanya surat yang masuk }\end{array}$ & $\begin{array}{l}\text { Tepat waktu dalam } \\
\text { melakukan penindakan } \\
\text { terhadap surat yang } \\
\text { masuk, sehingga } \\
\text { pekerjaan menjadi lebih } \\
\text { efisien dan optimal. }\end{array}$ \\
\hline 2. & $\begin{array}{l}\text { Pengelolaan } \\
\text { bersifat manual }\end{array}$ & $\begin{array}{l}\text { Pengelolaan } \\
\text { menggunakan } \\
\text { sistem aplikasi }\end{array}$ & $\begin{array}{l}\text { Memudahkan pekerjaan } \\
\text { para pegawai karena } \\
\text { dengan menggunakan } \\
\text { sistem aplikasi } \\
\text { pengelolaan }\end{array}$ \\
\hline 3. & $\begin{array}{l}\text { Penyimpanan Arsip } \\
\text { masih secara manual }\end{array}$ & $\begin{array}{l}\text { Penyimpanan semua arsip } \\
\text { dan kegiatan pegawai } \\
\text { tersimpan pada sebuah } \\
\text { database }\end{array}$ & $\begin{array}{lr}\text { Mudahnya pencarian } \\
\text { arsip ketika dibutuhkan } \\
\text { kembali, dan } \\
\text { meminimalisir hilangnya } \\
\text { arsip }\end{array}$ \\
\hline 4. & $\begin{array}{l}\text { Kepala Dinas mengecek } \\
\text { satu persatu pekerjaan } \\
\text { para pegawai setiap ada } \\
\text { keterlambatan proses } \\
\text { surat }\end{array}$ & $\begin{array}{l}\text { Dapat langsung } \\
\text { memonitoring pekerjaan } \\
\text { pegawai menggunakan } \\
\text { aplikasi pengelolaan }\end{array}$ & $\begin{array}{l}\text { Memberikan informasi } \\
\text { lebih terpercaya kepada } \\
\text { Kepala Dinas tentang } \\
\text { kinerja para pegawainya } \\
\text { jika } \\
\begin{array}{ll}\text { keterlambatan } & \text { terjadi } \\
\text { surat } & \end{array}\end{array}$ \\
\hline
\end{tabular}

\section{Simpulan}

Sistem notifikasi pesan disposisi pada pengelolaan surat menggunakan layana API media social Telegram pada Dinas Pertanian Kota Salatiga dibangun berbasis web telah dapat berfungsi untuk mengirimkan notifikasi ketika adanya surat masuk yang selesai disimpan dan ditujukan kepada pegawai yang ditentukan untuk segera dapat ditindaklanjuti. Dengan menggunakan Sistem Notifikasi Pesan Disposisi Pada Pengelolaan Surat Menggunakan Layana API Media Social Telegram Pada Dinas Pertanian Kota Salatiga sangat membantu dalam menindaklanjuti Surat Dinas agar dapat segera ditindaklanjuti oleh para pegawai yang menerima notifikasi dari aplikasi. Saran pengembangan penelitian selanjutnya adalah pengembangan layanan notifikasi menggunakan layanan API media social yang lebih lengkap atau lebih dari satu layanan notifikasi, dan yang lebih popular. 


\section{Daftar Pustaka}

[1] Maulana, Rizki., 2015. "Pengembangan Sistem Informasi Pengelolaan Surat Masuk dan Surat Keluar Berbasis Web di Dinas Sosial Tenaga Kerja dan Transmigrasi Kabupaten Garut Menggunakan framework PHP”. Garut: Sekolah Tinggi Teknologi Garut.

[2] Fitrianda, Haris., 2015. "Sistem Informasi Pengelolaan Surat Masuk Dan Surat Keluar Paa KPP XYZ Palembang”. Palembang: STMIK GI MDP Palembang.

[3] Hasan, L.O.M, Sholeh, M., Iswahyudi, C., Pemanfaatan Twitter API Untuk Mengakses Jadwal Bimbingan Dosen Pada IST AKPRIND Yogyakarta, Jurnal SCRIPT: Vol. 3, No. 2. 2016. ISSN:2338-6313: hal 173-181.

[4] Indrapermana, Yusa, 2017. "Pengertian Application Programming Interface (API)". http://www.yusaindera.com/2017/03/pengertian-applicationprogramming.html. Diakses pada tanggal 21 November 2017.

[5] Nesaba Media. "Kenali Pengertian Website Beserta Manfaat dan Jenis-Jenis Website". http://www.nesabamedia.com/pengertian-website/. Diakses pada tanggal 21 November 2017.

[6] Telegram (Aplikasi), diperoleh dari https://id.wikipedia.org/wiki/Telegram_(aplikasi)/. Diakses pada tanggal 21 November 2017.

[7] Pressman, R.S. 2001. Software Enginering : A Practitioner's Approach. Amerika Serikat: R.S. Pressman and Associates

[8] Sulistyorini, Prastuti. "Pemodelan Visual dengan Menggunakan UML dan Rational Rose". STMIK Widya Pratama : Pekalongan. 